\title{
Implementasi Permenkes Nomor 72 Tahun 2016 tentang Standar Pelayanan Kefarmasian di Rumah Sakit Terhadap Tatakelola SDM Instalasi Farmasi Rsu Mayjen H.A Thalib Kerinci Tahun 2018
}

Trianengsih $\mathrm{AT}^{1}$, Hardisman ${ }^{2}$, Dedy Almasdy ${ }^{3}$

\begin{abstract}
Abstrak
Permenkes 72 tahun 2016 sangat penting di terapkan di setiap Instalasi Farmasi di rumah sakit, sehingga tercapainya peningkatan mutu Pelayanan Kefarmasian. Tujuan penelitian ini adalah mengetahui bagaimana implementasi Permenkes No.72 Tahun 2016 tentang standar pelayanan kefarmasian terhadap tata kelola SDM Instalasi farmasi RSU Mayjen H.A Thalib Kerinci Tahun 2018 dengan menganalisis kualifikasi, persyaratan serta Beban kerja dan kebutuhan SDM di IFRS MHAT. Penelitian ini menggunakan desain Sequential Explanatory menggabungkan kuantitatif dan kualitatif dan penelitian kuantitatif adalah 28 orang, untuk informan pada penelitian kualitatif adalah 9 orang. Waktu penelitian dari Nopember sampai Desember 2018 di RSU Mayjen H.A Thalib Kerinci. Hasil penelitian adalah kualifikasi tenaga TKK masih ada dengan latar belakang SMF, Hasil check list dokumen didapatkan jika pengelolaan sediaan farmasi, alat kesehatan, dan bahan medis habis pakai $44,4 \%$ belum terlaksana sedangkan pelayanan farmasi klinik $63,6 \%$ belum terlaksana. Hasil pengamatan work sampling didapatkan hasil jika unit gudang dan rawat jalan memiliki produktivitas sedang, sedangkan untuk unit rawat inap menunjukkan tingkat produktivitas rendah. Kualifikasi, persyaratan serta Beban kerja dan kebutuhan SDM di IFRS MHAT belum sesuai dengan Permenkes 72 tahun 2016.
\end{abstract}

Kata kunci: SDM, Permenkes 72 tahun 2016, kualifikasi, persyaratan, beban kerja

\begin{abstract}
Regulation of the Minister of Health Number 72 of 2016 is very important to be applied in every Pharmacy Installation in a hospital, so that the achievement of improving the quality of Pharmaceutical Services is achieved. The objective of this study was to find out how the implementation of Minister of Health Regulation number 72 of 2016 concerning pharmaceutical service standards on Human Resourse (HR) management of RSU Pharmacy Installation Major General H.A Thalib Kerinci in 2018 by analyzing qualifications, requirements and workload and HR needs in IFRS MHAT. This study uses Sequential Explanatory design combining quantitative and qualitative and quantitative research is twenty-eight people, for informants in the qualitative study were nine people. During the study from November to December 2018 at the General Hospital of Maj. Gen. H. Thalib Kerinci. The results of this study were the qualifications of TKK personnel still with a background in SMF. The results of the document check list were obtained if the management of pharmaceutical preparations, medical devices, and medical materials were used up $44.4 \%$ had not been implemented while clinical pharmacy services $63.6 \%$ had not been implemented. The results of the work sampling observation showed that the warehouse and outpatient units had moderate productivity, while the inpatient unit showed a low level of productivity. Qualifications, requirements and workload and human resource requirements at IFRS MHAT are not yet in accordance with Minister of Health Regulation number 72 of 2016.
\end{abstract}

Keywords: HR, Regulation of the minister of health number 72 Year 2016, qualifications, requirements, workload 
Affiliasi penulis: 1. RSU Mayjen H.A Thalib Kerinci, 2. Bagian IImu Kesehatan Masyarakat Fakultas Kedokteran Universitas Andalas Padang, 3. Fakultas Kesehatan Masyarakat Universitas Andalas Korespondensi : Trianengsih. Email:ATtrianengsih22@gmail.com Telp: 085274326742

\section{PENDAHULUAN}

Standar Pelayanan Farmasi Rumah Sakit sebagaimana tercantum dalam Standar Pelayanan Rumah Sakit masih bersifat umum, maka untuk membantu pihak rumah sakit dalam mengimplementasikan Standar Pelayanan Rumah Sakit tersebut perlu dibuat Standar Pelayanan Farmasi di Rumah Sakit. ${ }^{1}$ Pada awalnya standar pelayanan farmasi di rumah sakit diatur di dalam Keputusan Menteri Kesehatan Republik Indonesia Nomor 1197/Menkes/Sk/X/2004, ${ }^{2}$ yang diatur kembali dengan Peraturan Menteri Kesehatan Nomor 58 Tahun $2014^{3}$ dan mengalami perubahan sampai dengan dengan Peraturan Menteri Kesehatan Nomor 72 Tahun $2016 .{ }^{4}$

Pengelolaan Instalasi Farmasi yang baik juga disadari betul oleh pihak manajemen yang memiliki visi "Menjadi Pusat Pelayanan Prima dan Mampu Memberikan Pelayanan yang Paripurna", yang merupakan pusat rujukan di wilayah Kabupaten Kerinci dan Kota Sungai Penuh'. Agar dapat memberikan pelayanan yang baik, terjangkau dan profesional, maka RSU MHAT harus pula dikelola secara profesional.Prinsip-prinsip efektifitas dan efesiensi, optimalisasi, benefit, dan cost harus menjadi indikator dalam pelaksanaannya dan diharapkan mampu menjalankan perannya untuk menjamin kelangsungan dan mutu pelayanan kesehatan bagi seluruh masyarakat. $^{5}$

Penelitian terdahulu yang terkait dengan pentingnya tata kelola Instalasi farmasi adalah penelitian yang dilakukan oleh Ikhlas (2017) dengan hasil analisis pelaksanaan Pharmaceutical Care pasien rawat jalan diRSUD Dr. M. Zein Painan belum maksimal/sesuai standar Permenkes nomor 58tahun 2014. ${ }^{6}$ penelitian yang dilakukan oleh Silva et al (2013) dengan hasil evaluasi peraturan apotek rumah sakit yang dikelola pemerintah di Rio de Janeiro dengan 62 indikator yang digunakan untuk menetapkan cakupan kegiatan farmasi rumah sakit, hasil 16 indikator yang sudah diterapkan. ${ }^{7}$
Menurut Permenkes Nomor 72 tahun 2016 tentang Standar Pelayanan Kefarmasian di RS, kebijakan pengelolaan sediaan farmasi, alat kesehatan dan bahan habis pakai harus dilaksanakan secara multi disiplin, terkoordinir dan menggunakan proses yang efektif untuk menjamin kendali biaya dan mutu. IFRS harus memiliki tenaga kerja yang sesuai dengan kualifikasi, persyaratan dan perhitungan beban kerja yang sesuai dengan standar dan kebutuhan rumah sakit agar tercapai sasaran dan tujuan IFRS . ${ }^{4}$

Berdasarkan Pelayanan Kefarmasian dan Penggunaan Obat (PKPO) 1 yang terdapat dalam SNARS 2017 pengorganisasian pelayanan kefarmasian dan penggunaan obat di rumah sakit harus sesuai dengan peraturan perundang-undangan dan diorganisir untuk memenuhi kebutuhan pasien dan untuk memastikan keefektifitasnya maka RS melakukan kajian sekurang-kurangnya sekali setahun. ${ }^{8}$ Dari latar belakang tersebut, maka perlu diadakan penelitian dengan judul: "Implementasi Permenkes RI Nomor 72 Tahun 2016 Tentang Standar Pelayanan Kefarmasian di Rumah Sakit Terhadap Tata Kelola SDM Instalasi Farmasi RSU Mayjen H. A Thalib Kerinci Tahun 2018".

\section{METODE}

Penelitian ini menggunakan metode penelitian kombinasi (mixed methods) dengan desain Sequential Explanatory yaitu metode penelitian kombinasi atau menggabungkan antara metode kuantitatif dan metode kualitatif untuk digunakan secara bersama-sama. ${ }^{9}$ Metode penelitian kuantitatif melakukan penghitungan beban kerja menggunakan metode check list dokumen dan metode work sampling di Unit Instalasi Farmasi RSU Mayjen H.A Thalib Kerinci sedangkan metode penelitian kualitatif dilakukan dengan wawancara mendalam, telaah dokumen dan observasi.

\section{Hasil}

\section{A. Hasil Penelitian Kuantitatif}

1. Penelitian check list dokumen standar pelayana kefarmasian dilakukan pada dua kegiatan yaitu pada kegiatan pengelolaan sediaan farmasi, alat kesehatan, dan bahan habis pakai serta pada kegiatan pelayanan farmasi klinik. 
Tabel 1. Hasil checklist dokumen standar kegiatan pengelolaan sediaan farmasi, alat kesehatan dan bahan habis pakai di RSU Mayjen HA Thalib Kerinci

\begin{tabular}{|c|c|c|c|c|c|c|c|}
\hline \multirow[t]{2}{*}{$\begin{array}{l}\text { Standar } \\
\text { Kegiatan }\end{array}$} & \multirow[t]{2}{*}{$\begin{array}{l}\text { Jumlah } \\
\text { Kegiatan }\end{array}$} & \multicolumn{2}{|c|}{ Belum } & \multicolumn{2}{|c|}{$\begin{array}{c}\text { On } \\
\text { Proses }\end{array}$} & \multicolumn{2}{|c|}{ Sudah } \\
\hline & & f & $\%$ & $f$ & $\%$ & $f$ & $\%$ \\
\hline Pemilihan & 8 & 3 & 11,1 & 1 & 3,7 & 4 & 14,8 \\
\hline $\begin{array}{l}\text { Perencanaan } \\
\text { kebutuhan }\end{array}$ & 6 & 6 & 3,7 & & & 5 & 18,5 \\
\hline Pengadaan & 6 & 5 & 18,5 & & & 1 & 3,7 \\
\hline Penerimaan & 2 & 1 & 3,7 & & & 1 & 3,7 \\
\hline Penyimpanan & 1 & & & & & 1 & 3,7 \\
\hline Pendistribusian & 1 & & & & & 1 & 3,7 \\
\hline $\begin{array}{l}\text { Pemusnahan \& } \\
\text { penarikan }\end{array}$ & S & 1 & 3,7 & & & & \\
\hline Pengendalian & 1 & 1 & 3,7 & & & & \\
\hline Administrasi & 1 & & & & & 1 & 3,7 \\
\hline Jumlah & 27 & 12 & 44,4 & 1 & 3,7 & 14 & 61,9 \\
\hline
\end{tabular}

Checklist dokumen standar pelayanan kefarmasian rumah sakit pada kegiatan pelayanan farmasi klinik dapat dilihat pada Tabel 2 dibawah ini.

Tabel 2. Hasil check list dokumen standar kegiatan pelayanan farmasi klinik di RSU MHAT Kerinci

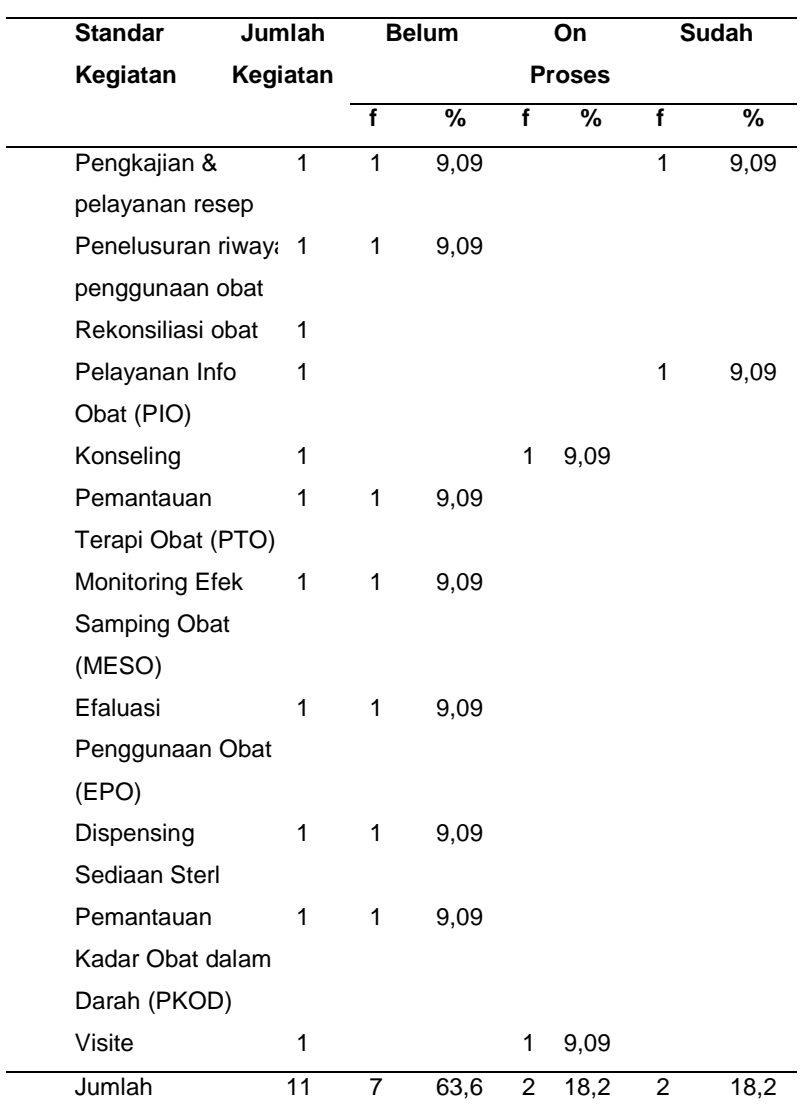

Hasil penelitian melalui check list dokumen untuk Kegiatan Pengelolaan sediaan farmasi, alat kesehatan dan bahan habis pakai di RSU MHAT 44,4 $\%$ belum terlaksana dan pelayanan farmasi klinik didapatkan $63,6 \%$ lagi kegiatan pelayanan yang belum dijalankan.

\section{Hasil Pengamatan Work Sampling}

Pendistribusian tenaga farmasi di IFRS MHAT belum sesuai dengan permenkes 72 tahun 2016 hanya terdistribusi pada tiga unit yaitu gudang, apotik rawat jalan dan apotik rawat inap/IGD

Hasil penelitian terkait produktivitas kerja di instalsi farmasi dilihat berdasarkan kategori aktivitas dan diukur berdasarkan hasil pengamatan work sampling yaitu aktivitas langsung, aktivitas tidak langsung serta aktivitas pribadi dan tidak produktif.

Tabel 3. Produktivitas instalasi farmasi RSU MHAT

\begin{tabular}{|c|c|c|c|c|}
\hline Unit & $\begin{array}{l}\text { Rerata } \\
\text { Resep }\end{array}$ & $\begin{array}{c}\text { Lagsung } \\
+ \\
\text { Tidak } \\
\text { langsung } \\
(\%)\end{array}$ & $\begin{array}{l}\text { Pribadi + } \\
\text { Tdak } \\
\text { Produktif } \\
\quad(\%)\end{array}$ & $\begin{array}{c}\text { Tingkat } \\
\text { Produk- } \\
\text { tifitas }\end{array}$ \\
\hline Gudang & 0 & 64,0 & 35,5 & Sedang \\
\hline Rawat Jalan & 89,6 & 64,4 & 36,6 & Sedang \\
\hline Rawat Inap & 1 & & & \\
\hline Shift 1 (pagi) & 66 & 52,1 & 47,9 & Rendah \\
\hline Shift 2 (sore) & 19,8 & 41,3 & 58,7 & Rendah \\
\hline Shift 3 (malam) & 34,2 & 27,7 & 72,3 & Rendah \\
\hline
\end{tabular}

Rendahnya produktivitas petugas di unit rawat inap disebabkan masih banyaknya kegiatan standar pelayanan kefarmasian yang belum terlaksana.

\section{B. Hasil Penelitian Kualitatif}

1. Kualifikasi Sumber Daya Manusia di Instalasi Farmasi

Berdasarkan telaah dokumen pada bagian kepegawaian diketahui bahwa kualifikasi SDM IFRS MHAT terdiri dari Apoteker, Apoteker S2 Kesehatan Masyarakat, S1 farmasi, DIII farmasi, SMF, DIII komputer dan S1 sosial. Berdasarkan hasil wawancara mendalam dan telaah dokumen disajikan dalam matrik triangulasi pada Tabel 4 berikut ini. 
Tabel 4. Matrik triangulasi metode tentang kualifikasi SDM

\begin{tabular}{llll}
\hline Topik & Wawancara & Dokumen & $\begin{array}{c}\text { Analisis } \\
\text { Triangulasi }\end{array}$ \\
\hline Kualifikasi & SDM yang & Ada dokumen & Kualifikasi SDM \\
SDM & ada di RSU & kepegawaian & yang ada di RSU \\
& MHAT terdiri & tentang & MHAT terdiri dari \\
& dari tenaga & rincian tenaga & Apoteker, S1 \\
apoteker, & kefarmasian & farmasi, DIII \\
tenaga teknik & di RSU MHAT & Farmasi, SMF,DIII \\
kefarmasian, & & Komputer dan S1 \\
dan & & Sosial, tetapi \\
pekerjaan & & masih \\
penunjang. & & kekurangan pada \\
Secara & & tenaga teknik \\
kualitas & & kefarmasian \\
masih ada & & sehingga masih \\
kekurangan & & memanfaatkan \\
pada tenaga & & tenaga SMF yang \\
teknik & & ada berdasarkan \\
kefarmasian & & kemampuan dan \\
& & &
\end{tabular}

\section{Persyaratan Sumber Daya Manusia}

Berdasarkan telaah dokumen tenaga Apoteker dan Tenaga Teknik Kefarmasian sudah memenuhi peryaratan administrasi yaitu apoteker mempunyai STRA dan TTK mempunyai SRTTK, selain itu ditemukan SK pengangkatan untuk jabatan fungsional yang diisi oleh Tenaga Teknik Kefarmasian. Hasil wawancara mendalam dan telaah dokumen disajikan dalam matrik triangulasi pada tabel. 05 berikut ini.

Tabel 5. Matrik triangulasi metode tentang persyaratan SDM

\begin{tabular}{|c|c|c|c|}
\hline Topik & Wawancara & Dokumen & $\begin{array}{c}\text { Analisis } \\
\text { Triangulasi }\end{array}$ \\
\hline $\begin{array}{l}\text { Persyaratan } \\
\text { SDM }\end{array}$ & $\begin{array}{lr}\text { Apoteker } & \text { yang } \\
\text { ada di } & \text { RSU } \\
\text { MHAT sudah } & \text { memiiki STRA } \\
\text { dan SIPA dan } & \\
\text { untuk Tenaga } \\
\text { Teknik } \\
\text { Kefarmasian } \\
\text { sudah meiliki } \\
\text { STRTTK dan } \\
\text { SIK, sedangkan } \\
\text { untuk jabatan } \\
\text { fungsionaldiisi } \\
\text { oleh tenaga } \\
\text { SMF karena } \\
\begin{array}{l}\text { pengalaman dan } \\
\text { kredibilitasnya }\end{array}\end{array}$ & $\begin{array}{l}\text { Ada dokumen } \\
\text { SK penetapan } \\
\text { jabatan } \\
\text { fungsional } \\
\text { tenaga SMF } \\
\text { sebagai } \\
\text { kepala } \\
\text { ruangan apotik }\end{array}$ & $\begin{array}{l}\text { Persyaratan } \\
\text { administrasi } \\
\text { SDM sudah } \\
\text { sesuai dengan } \\
\text { Permenkes } 72 \\
\text { tahun 2016dan } \\
\text { persyaratan } \\
\text { untuk jabatan } \\
\text { fungsional } \\
\text { yang ada di } \\
\text { instalasi } \\
\text { farmasi RSU } \\
\text { MHAT belum } \\
\text { sesuai dengan } \\
\text { Permenkes } 72 \\
\text { tahun } 2016 .\end{array}$ \\
\hline
\end{tabular}

\section{Beban Kerja dan Kebutuhan}

Berdasarkan telaah dokumen yang dilakukan, diketahui tidak ditemukannya dokumen bentuk laporan visite ruangan yang dilakukan apoteker, hasil wawancara mendalam dan telaah dokumen disajikan dalam matrik triangulasi pada tabel.06 berikut ini.

Tabel 6. Matrik triangulasi metode tentang pelaksanaan visite

\begin{tabular}{llll}
\hline \multicolumn{1}{c}{ Topik } & Wawancara & Dokumen & $\begin{array}{c}\text { Analisis } \\
\text { Triangulasi }\end{array}$ \\
\hline Pelayanan & Pelayanan visite & Tidak ada & Pelayanan \\
Farmasi & diruangan sudah & dokumen & visite sudah \\
Visite & dilaksanakan & pelaporan & dilaksanakan, \\
& tetapi tidak rutin & hasil visite & tetapi tidak \\
& dan tidak ada & & rutin dan \\
& dibuat laporan & & setiap visite \\
& & & dilakukan \\
& & & tidak ada \\
& & & laporannya \\
\hline
\end{tabular}

Berdasarkan uraian tugas instalasi farmasi di ketahui pendistribusian tenaga farmasi belum sesuai dengan permenkes 72 tahun 2016 hanya terdistribusi pada tiga unit yaitu gudang, apotik rawat jalan dan apotik rawat inap/IGD.Unit apotik rawat jalan danrawat inap IGD penempatan tenaga apoteker tanpa mempertimbangkan jumlah resep yang dilayani.

Permenkes 72 tahun 2016 penempatan tenaga apoteker bila dihubungkan dengan jumlah resep yang mana bila disesuaikan dengan jumlah tempat tidur rawat inap RSU MHAT ${ }^{4}$ dan berdasarkan Permenkes no. 80 tahun 2016 dalam menyusun perencanaan Tenaga Kesehatan harus memperhatikan faktor diataranya dengan mempertimbangkan letak kondisi georafis dari unit layanan, ${ }^{12}$ maka seharusnya penempatan atau distribusi tenaga apoteker adalah seperti yang terdapat pada Tabel 7 dibawah ini 
Tabel 7. Pendistribusian tenaga apoteker di sesuaikan dengan Permenkes 72 tahun 2016 disesuaikan letak dan jangkauan unit setiap layanan di RSU MHAT

\begin{tabular}{|c|c|c|c|}
\hline No & Unit Distibusi Apoteker & $\begin{array}{c}\text { Jumlah } \\
\text { Tempat } \\
\text { Tidur }\end{array}$ & $\begin{array}{l}\text { Jumlah } \\
\text { Apoteker }\end{array}$ \\
\hline 1 & Kepala Instalasi Farmasi & - & 1 \\
\hline 2 & Penyakit Dalam & 27 & 1 \\
\hline 3 & Bedah & 16 & 1 \\
\hline 4 & $\begin{array}{l}\text { Anak, Perinatologi, } \\
\text { Kebidanan }\end{array}$ & 33 & 1 \\
\hline 5 & $\begin{array}{l}\text { THT, Mata dan VIP } \\
\text { Danau Lingkat }\end{array}$ & 13 & 1 \\
\hline 6 & Neurologi dan Jantung & 19 & 1 \\
\hline 7 & Paru-paru & 16 & 1 \\
\hline 8 & Gunung Tujuh & 18 & 1 \\
\hline 9 & IDD dan ICU & 12 & 1 \\
\hline 10 & $\begin{array}{l}\text { VIP : Bukit Kayangan, } \\
\text { Gunung Kerinci, Danau } \\
\text { Kerinci dan Suite Room }\end{array}$ & 29 & 1 \\
\hline 11 & Gudang Farmasi & - & 1 \\
\hline & Jumlah & 171 & 12 \\
\hline
\end{tabular}

Berdasarkan laporan Indikator penampilan Rumah Sakit Tahun 2013 sampai 2018 diketahui angka Bed Occupancy Ratio (BOR) tahun $2018,{ }^{10}$ tidak setara dengan rata-rata resep yang dilayani perhari tahun $2018 .^{11}$

\section{PEMBAHASAN}

\section{Kualifikasi SDM}

Berdasarkan hasil penelitian SDM IFRS MHAT masih terdapat TTK dengan latar belakang pendidikan SMF yaitu sebanyak 7 orang sedangkan menurut Permenkes No 72 Tahun 2016 kualifikasi untuk tenaga TTK adalah Sarjana Farmasi dan Analis Farmasi. ${ }^{4}$ Selain Permenkes 72 tahun 2016 untuk persyaratan TTK juga diatur dalam Permenkes RI nomor 80 tahun 2016 tentang Asisten Penyelenggaraan Kesehatan bahwa Asisten Tenaga Kesehatan adalah setiap orang yang mengabdikan diri dalam bidang kesehatan serta memiliki pengetahuan dan keterampilan melalui bidang kesehatan di bawah jenjang Diploma Tiga (DIII). ${ }^{12}$

Berdasarkan pada UU nomor 36 tahun 2014 tentang tenaga kesehatan yang menetapkan kualifikasi minimum yakni DIII kecuali tenaga medis dimana tenaga kesehatan yang belum memiliki kualifikasi pendidikan DIII, akan menjadi asisten Tenaga Kesehatan dan tidak bisa melaksanakan praktek, dimana tujuan dari peningkatan pendidikan ini adalah untuk peningkatan kebutuhan dari pelayanan kesehatan. ${ }^{13}$ Tuntutan pasien dan masyarakat akan mutu pelayanan farmasi, mengharuskan adanya perubahan pelayanan dari pardigma lama drug oriental ke paradigma baru patient oriental dengan filosofi pharmaceutical care (pelayanan kefarmasian). ${ }^{14}$ Hasil penelitian ini hampir sama dengan penelitian yang dilakukan oleh Novita (2016), didapatkan perencanaan SDM belum terintegrasi, penilaian kinerja instalasi farmasi belum ada, kredential dan re-kredential belum pernah dilaksanakan. Kredential merupakan proses evaluasi oleh suatu rumah sakit terhadap seseorang untuk menentukan apakah yang bersangkutan layak diberikan kewenangan klinis, menjalankan tindakan dalam rumah sakit tersebut untuk periode tertentu. ${ }^{15}$

Pengelolaan SDM dengan kualifikasi pendidikan SMF mestinya mendapat perhatian dari pihak manajemen rumah sakit khususnya bagian kepegawaian, seharusnya menitik beratkan semua tenaga farmasi yang masih berlatar belakang SMF untuk meningkatkan keahlian dan pendidikannya menjelang tahun 2020 baik melaui jalur RPL atau pun mandiri, sehingga tahun 2020 kualifikasi pendidikan tenaga kesehatan minimal DIII dapat tercapai.

\section{Persyaratan SDM}

SDM IFRS MHAT Kerinci, semua sudah memenuhi persyaratan administrasi yaitu untuk apoteker dengan persyaratan memiliki STRA dan SIPA sedangkan untuk TTK memiliki STRTTK dan SIK. Dari uraian tugas ada petugas apotik yang diberi jabatan Kepala Ruangan untuk masing-masing apotik dengan uraian tugas bertanggung jawab atas kelancaran tugas Ka. Instalasi Farmasi di apotik yang dengan SuratKerja yang ditandatangani oleh direktur dan untuk Kepala Ruangan apotik rawat inap masih menggunakan tenaga TTK dengan kualifikasi SDM tamatan SMF hal ini berdasarkan pertimbangan atas kemampuan dan kredibilitas tenaga tersebut.

Tujuan dari standar pelayanan kefarmasian menurut permenkes no. 72 tahun 2016 adalah tercapai peningkatan mutu pelayanan kefarmasian, menjamin kepastian hukum bagi tenaga kefarmasian, melindungi pasien dan masyarakat dari penggunaan obat yang tidak rasional dalam rangka keselamatan pasien (patient safety). ${ }^{4}$ Dalam hal ini sebaiknya manajemen 
RSU MHAT menata ulang kembali struktur organisasi dan jabatan fungsional yang ada di instalasi farmasi dengan mementingkan tujuan pelayanan yang sesuai standar pelayanan kefarmasian dirumah sakit, tidak hanya mempertimbangkan atas kemampuan dan kredibilitas tapi harus mempertimbangkan apa yang menjadi tujuan standar pelayanan kefarmasian.

\section{Beban Kerja dan Kebutuhan}

\section{Pelaksanaan Pelayanan Kefarmasian Berdasarkan} check list.

Petugas farmasi mengganggap jika tidak ada pasien yang membutuhkan pelayanan farmasi, maka mereka tidak perlu melakukan pekerjaan farmasi lainnya, seharusnya menurut Permenkes No 72 Tahun 2016 standar pelayanan farmasi tidak hanya terfokus pada menerima resep, tetapi banyak aktivitas yang harus dilakukan agar dapat memenuhi standar pelayanan kefarmasian, kegiatan tersebut dibagi menjadi dua yaitu kegiatan pengelolaan sediaan farmasi, alat kesehatan dan bahan habis pakai. Serta kegiatan pelayanan. ${ }^{4}$

Kegiatan Pengelolaan sediaan farmasi, alat kesehatan dan bahan habis pakai RSU MHAT 44,4\% belum terlaksana. Hal ini sama dengan penelitian yang dilakukan oleh da Silva et al (2013) evaluasi peraturan dengan 62 indikator digunakan untuk menetapkan cakupan kegitan farmasi rumah sakit, hasil 16 indikator sudah diterapkan. Evaluasi kinerja mengungkapkan hanya 1 unit yang melakukan kegiatan manajemen dan perencanaan yang memuaskan. Empat unit administrasi pengadaan obat tidak memadai. Hasil terburuk dalam hal kinerja di enam rumah sakit yang diteliti terkait dengan manajemen stok dan yang kegiatan distribusi. $^{7}$

Pelaksanaan pelayanan farmasi klinik yang dilakukan penelitian melalui check list dokumen juga didapatkan hasil jika masih 63,6\% lagi kegiatan pelayanan yang belum dijalankan.kegiatan yang belum dijalankan tersebut antara lain penelusuran riwayat penggunaan obat, rekonsiliasi obat, pemantauan terapi obat (PTO), monitoring efek samping obat, evaluasi penggunaan obat, dispensing sediaan steril dan pemantauan kadar obat dalam darah. Belum dijalankan kegiatan tersebut karena masih terkendala dengan kurangnya tenaga yang ada, sehingga kegiatan pelayanan farmasi klinik hanya sebatas pada pengkajian dan pelayanan resep serta Pelayanan Informasi Obat (PIO). Penelitian Perez et al (2009) tentang pentingnya pelayanan farmasi klinik, layanan farmasi klinis terus memberikan pengembalian investasi yang signifikan, tetapi perbaikan masih diperlukan dalam metode yang digunakan untuk mengevaluasi dampak ekonomi dari layanan ini. ${ }^{17}$ Pelayanan Informasi Obat juga merupakan bagian penting dalam pelayanan farmasi klinik karena berpangaruh terhadap kepuasan pasien. Hal ini sesuai dengan penelitian yang dilakukan oleh Amaranggana (2017) yang melakukan review terhadap pelayanan farmasi klinik khusus pada pelayanan informasi obat yang mendapatkan hasil jika masih ada sekitar $44 \%$ belum menerapkan PIO, 42\% baru menerapkan PIO dan hanya $14 \%$ rumah sakit yang telah menerapkan $\mathrm{PIO}$, pentingnya dilakukan monitoring dan evaluasi terhadap PIO ini karena berdampak terhadap mutu pelayanan di rumah sakit.$^{18}$

Pelaksanaan pengelolaan sediaan farmasi, alat kesehatan, dan bahan medis habis pakai serta pelayanan farmasi klinik haruslah didukung oleh ketersediaan sumber daya kefarmasian dan pengorganisasian yang berorientasi kepada keselamatan pasien dan standar prosedur operasional. Diharapkan manajemen RSU MHAT benar-benar bisa menyediakan sumber daya terutama sumber daya manusia sebagai pelaku utama dalam melaksanakan kegiatan kefarmasian, sumberdaya yang diharapkan tersebut haruslah mencukupi dari segi kuantitas dan memiliki kompetensi serta pengalaman dan pengetahuan yang sesuai dengan kefarmasian, semua ini bertujuan untuk meningkatkan kualitas pelayanan farmasi di RSU Mayjen H.A Thalib Kerinci.

Seluruh kegiatan pelaksanaan pengelolaan sediaan farmasi, alat kesehatan, dan bahan medis habis pakai serta pelayanan farmasi klinik sangatlah penting dilaksanakan secara keseluruhan karena menurut Permenkes 72 tahun 2016 pelaksanaan pengelolaan sediaan farmasi, alat kesehatan, dan bahan medis habis pakai yang dilaksanakan secara multi disiplin dan menggunakan proses yang efektif bertujuan untuk menjamin kendali mutu dan kendali biaya, sedangkan pelayanan farmasi klinik merupakan pelayanan langsung yang diberikan oleh apoteker 
kepada pasien dalam rangka meningkatkan outcome terapi dan meminimalkan risiko terjadinya efek samping obat, untuk tujuan keselamatan pasien (patient safety) sehingga kualitas hidup pasien (quality of life) terjamin. ${ }^{4}$ Manajemen rumah sakit harus mengkoordinir pelaksanaan semua kegiatan standar pelayanan kefarmasian di rumah sakit sesuai dengan tipe rumah sakit dengan membuat tata kelola pelaksanaan kegiatan kefarmasian yang sesuai dengan permenkes 72 tahun 2016 sehingga semua pelayanan kefarmasian dapat terlaksana sesuai dengan standar pelayanan kefarmasian. ${ }^{4}$

\section{Hasil Pengamatan Produktifitas Masing-masing Unit} di Instalasi Farmasi dengan Metode Work Sampling

Berdasarkan hasil penelitian dilapangan pada seluruh tenaga farmasi yang berada pada unit rawat jalan, unit rawat inap dan gudang farmasi dengan melakukan pengamatan pada aktivitas langsung, aktifitas tidak langsung, aktivitas pribadi dan aktivitas tidak langsung. Fakta dilapangan diketahui bahwa produktiviitas tenaga farmasi digudang dan rawat jalan masih berada dalam kategori sedang karena banyak melakukan kegiatan langsung yang dibarengi dengan melakukan kegiatan tidak produktif, sedangkan pada unit rawat inap produktivitas tenaga farmasi berada pada kategori rendah disebabkan banyak melakukan kegiatan tidak produktif.

Penelitian yang dilakukan Herwina (2017) yang melakukan penghitungan kerja dengan menggunakan metode work sampling di instalasi farmasi menunjukkan hasil jika beban kerja tenaga asisten apoteker di Instalasi Farmasi sudah tinggi karena total waktu kegiatan tenaga apoteker mencapai 86,48\% atau sudah melebihi standar optimum yaitu $80 \%$, berarti jumlah SDM yang ada memang tidak sebanding dengan pelayanan resep. ${ }^{19}$ Cega (2017) yang melakukan analisis beban kerja dan kebutuhan tenaga kerja karyawan divisi logistik dengan metode work sampling dengan hasil penelitian yaitu 4 unit dari 9 unit departemen memiliki masalah beban kerja yaitu overload dan 1 unit lainnya underload. ${ }^{20}$ Rahmayanti (2017) dalam penelitiannya juga mendapatkan hasil jika jumlah pegawai yang ada akan berpengaruh terhadap beban kerja pegawai yang nantinya akan menghambat sistem distribusi obat, hal ini disebabkan kurangnya SDM, sarana prasaran dan proses pendistribusian yang kurang optimal, keterlambatan pendistribusian obat. ${ }^{21}$

Berdasarkan hasil pengamatan diatas rendahnya produktifitas disebabkan masih banyaknya kegiatan standar pelayanan kefarmasian yang belum terlaksana, untuk meningkatkan produktifitas dari SDM IFRS MHAT manajemen hendaknya mengarahkan IFRS MHAT untuk melaksanakan seluruh kegiatan pelayanan sesuai dengan Permenkes 72 tahun 2016 dengan memberikan pembekalan berupa pelatihan-pelatihan yang terkait dengan keahlian pelayanan yang akan dilakukan sehingga meningkatkan mutu pelayanan tersebut dilapangan dan tujuan standar pelayan kefarmasian di rumah sakit dapat tercapai, hal ini sesuai dengan penelitian yang dilakukan oleh Teichert (2013) dengan hasil setelah pelatihan yang tepat, di apotek dengan apoteker yang terlatih khusus, $63 \%$ dari pasien terpilih menerima ulasan pengobatan lengkap, ini 12\% lebih tinggi dari pada di apotek tanpa apoteker terlatih. ${ }^{22}$

3. Penghitungan kebutuhan tenaga pada Pelayanan Kefarmasian di IFRS MHAT

Menurut Permenkes 72 tahun 2016 untuk menghitung beban kerja perlu diperhatikan faktor-faktor yang berpengaruhi pada kegiatan yang dilakukan, yaitu: Kapasitas tempat tidur / Bed Occupancy Rate (BOR); Jumlah dan jenis kegiatan farmasi yang dilakukan (manajemen, klinik dan produksi); Jumlah resep atau formulir permintaan obat per hari; dan volume Sediaan Farmasi, Alat Kesehatan, dan Bahan Medis Habis Pakai. ${ }^{4}$

Berdasarkan laporan Indikator penampilan rumah sakit tahun 2013 - 2018 diketahui angka Bed Occupancy Ratio (BOR) tahun 2018 yaitu 87\% yang berati penggunaan tempat tidur dalam tahun $2018 .{ }^{10}$ adalah 163 tempat tidur perhari tidak setara dengan rata-rata resep yang dilayani perhari tahun 2018 yaitu dibawah 100 resep perhari, ${ }^{11}$ ini berarti ada sebagian pasien yang tidak dilayani resepnya di apotik rawat inap/IGD, dari hasil pengamatan dilapangan hal ini disebabkan sebagian resep tidak tercatat di laporan pelayanan resep di apotik adalah resep yang obatnya tidak ada di apotik dengan kata lain obat di beli di apotik diluar rumah sakit dan resep yang ditulis oleh perawat. 
Pelayanan kegiatan kefarmasian juga harus didukung dengan adanya Standar Operasional Prosedur (SOP) yang jelas, SOP adalah urutan langkah-langkah dimana pekerjaan tersebut dilakukan, berhubungan dengan apa yang dilakukan, bagaimana melakukannya, bilamana melakukannya, dimana melakukannya dan siapa yang melakukannya. ${ }^{23}$ dengan tidak adanya SOP membuat petugas kefarmasian ragu atau tidak tahu dalam melakukan pengelolaan sehingga berakibat terjadinya kesalahan seperti ada resep obat yang dibuat oleh perawat yang tidak dimasukkan kedalam jumlah resep yang keluar, padahal resep tersebut tetap dilayani, untuk pihak manajemen harus membuat SOP yang mengatur bagaimana seharusnya pengelolaan kefarmasian di RSU MHAT sesuai dengan Permenkes 72 tahun 2016 dimana SOP dibuat oleh pimpinan rumah sakit dengan ketentuan perundang-undangan, sehingga semua tenaga farmasi benar-benar memahami apa saja yang harus mereka lakukan dan punya acuan dalam melaksanakan kegiatan, sehingga resiko terjadinya kesalahan akan semakin kecil. ${ }^{4}$

Pendistribusian tenaga farmasi di IFRS MHAT belum sesuai dengan permenkes 72 tahun 2016 hanya terdistribusi pada tiga unit yaitu gudang, apotik rawat jalan dan apotik rawat inap/IGD, untuk apotik rawat jalan dan rawat inap IGD penempatan tenaga apoteker tanpa mempertimbangkan jumlah resep yang dilayani yaitu 30 resep dilayani oleh 1 orang apoteker untuk rawat inap dan 50 resep dilayani oleh satu orang apoteker. ${ }^{4}$

Penyediaan tenaga kesehatan di rumah sakit ditujukan untuk mengatur tenaga kesehatan di rumah sakit baik dari segi jumlah, jenis kualifikasi dan mutu serta penyebarannya yang seharusnya dilakukan melalui perencanaan. Untuk itu kedepannya manajemen hendaknya melakukan suatu perencanaan kebutuhan sumber daya manusia di rumah sakit dengan melakukan analisis jabatan yang berguna untuk landasan untuk melaksanakan mutasi, landasan untuk melaksanakan promosi, landasan untuk melaksanakan training/ pelatihan, landasan untuk melaksanakan kompensasi, landasan untuk melaksanakan syarat lingkungan kerja, landasan untuk pemenuhan kebutuhan peralatan. Analisis jabatan bermanfaat dari analisis pekerjaan adalah membantu dalam mengkomunikasikan harapan sebuah pekerjaan terhadap si pemegang jabatan, penyelia dan rekan sejawatnya. Dengan menjabarkan pekerjaan apa yang dibutuhkan, bagaimana kualifikasi orang yang akan memegangnya, kapan waktu yang dibutuhkan untuk menciptakan pekerjaan baru itu dan bagaimana syarat-syarat yang akan dibutuhkan maka akan terjadi efisiensi pemakaian tenaga kerja dan optimalisasi produktivitas.$^{24}$

\section{SIMPULAN}

Tenaga TKK masih dengan latar belakang SMF sedangkan menurut Permenkes 72 Tahun 2016 seharusnya kualifikasi untuk tenaga TKK adalah sarjana farmasi dan DIII farmasi.

Persyaratan administrasi SDM di IFRS MHAT sudah sesuai dengan Permenkes No 72 Tahun 2016.

Hasil pengamatan dengan metoda work sampling didapatkan hasil jika unit gudang dan rawat jalan memiliki produktivitas sedang, sedangkan untuk unit rawat inap menunjukkan tingkat produktivitas rendah.

Penghitungan kebutuhan tenaga pada Pelayanan Kefarmasian belum sesuai dengan permenkes 72 tahun 2016.

\section{SARAN}

Manajemen rumah sakit khususnya bagian kepegawaian, seharusnya menitik beratkan semua tenaga farmasi yang masih berlatar belakang SMF untuk meningkatkan keahlian, pendidikan dan menata ulang kembali struktur organisasi dan jabatan fungsional yang ada di instalasi farmasi dengan mementingkan tujuan pelayanan yang sesuai standar pelayanan kefarmasian rumah sakit.

Manajemen rumah sakit mengkoordinir pelaksanaan semua kegiatan standar pelayanan kefarmasian dengan membuat tata kelola pelaksanaan kegiatan kefarmasian dan mengarahkan pelaksanaan seluruh kegiatan yang sesuai dengan permenkes 72 tahun 2016, memberikan pembekalan berupa pelatihan yang dibutuhkan sesuai dengan bidang pelayanan yang akan dilaksanakan dan melakukan suatu perencanaan kebutuhan sumber daya manusia dengan melakukan analisis jabatan. 


\section{UCAPAN TERIMA KASIH}

Terimakasih kepada seluruh pihak yang turut membantu dalam menyelesaikan penelitian ini yaitu Direktur RSU MHAT beserta manajemen dan Kepala Instalasi Farmasi beserta Staf.

\section{DAFTAR PUSTAKA}

1. Departemen Kesehatan RI. Profil Kesehatan Indonesia tahun 2016. Jakarta: Departemen Kesehatan Rl; 2016.

2. Kementrian Kesehatan RI. Keputusan menteri kesehatan nomor 1197/Menkes/Sk/X/2004 tentang pelayanan farmasian di rumah sakit. Kementrian Kesehatan Rl; 2004.

3. Kementrian Kesehatan Republik Indonesia. Peraturan menteri kesehatan no.58 tahun 2014 tentang pelayanan kefarmasian. Kementrian Kesehatan RI; 2014

4. Kementrian Kesehatan Republik Indonesia. Peraturan Menteri Kesehatan No.72 Tahun 2016 tentang Pelayanan Kefarmasian. Kementrian Kesehatan RI; 2016

5. Rumah Sakit Umum Daerah Mayjen HA Thalib (RSUD MHAT). Profil RSUD MHAT. Kerinci: RSUD MHAT; 2017

6. Ikhlas C. Analisis pelaksanaan pharmaeutical care pasien rawat jalan di RSUD $\operatorname{Dr} M$ Zein Painan [tesis]. Padang: Fakultas Farmasi Universitas Andalas; 2017

7. Silva M J S, Torres R M, Oliveira M A, Castro C G S $\mathrm{O}$. Improving population health through integration of primary care and public health: providing access to physical activity for community health center patients. Am J Public Healtth. 2012; 102 (11); e56e61.

8. Komisi Akreditasi Rumah Sakit. Standar akreditasi rumah sakit edisi 1. Komisi akreditasi Rumah Sakit; 2017.

9. Sugiyono. Metode penelitian kombinasi. Bandung: Alfabeta; 2016.

10. Rumah Sakit Umum Daerah Mayjen H.A Thalib. Indikator penampilan rumah sakit tahun 20132018. Kerinci: RSUD MHAT; 2018

11. Rumah Sakit Umum Daerah Mayjen H.A Thalib. Jumlah rata-rata resep per hari tahun 2018. Kerinci: RSUD MHAT; 2018.
12. Departemen Kesehatan RI. Peraturan menteri kesehatan Republik Indonesia nomor 80 tahun 2016 tentang penyelenggaraan pekerjaan Asisten Tenaga Kesehatan. Jakarta: Departemen Kesehatan RI; 2016.

13. Undang-undang Republik Indonesia Nomor 36 Tahun 2014 Tentang Tenaga Kesehatan. Jakarta: 2014

14. Febriawati $\mathrm{H}$. Manajemen logistik farmasi rumah sakit. Yogyakarta: Gosyen Publishing; 2013.

15. Novita D. Analisis persiapan dokumen standar kualifikasi dan pendidikan staf instalasi farmasi di RSI Siti Rahmah dalam memenuhi elemen penilaian standar akreditasi versi 2012 tahun 2015 [tesis]. Prodi Magister Administrasi Rumah Sakit Universitas Andalas Padang; 2016.

16. Departemen Kesehatan RI. Peraturan menteri kesehatan Republik Indonesia nomor 72 tahun 2016 tentang pelayan kefarmasian rumah sakit. Jakarta: Departemen Kesehatan RI; 2016.

17. Perez A, DolorescoF, Hoffman JM,Touchette DR, Vermeulen LC, Schumock GT. ACCP: Economic evaluations of clinical pharmacy services. Pharmacotherapy. 2009 Jan; 29(1):128.

18. Amaranggana L. Pelayanan informasi obat yang efektif dari beberapa negara untuk meningkatkan pelayanan farmasi klinik. Jurnal Farmaka. 2017;15 (1):1-7.

19. Herwina D. Gambaran beban kerja tenaga asisten apoteker di instalasi farmasi RSU kota Tanggerang tahun 2017 (skripsi). Jakarta: Prodi Kesehatan Masyarakat Universitas Islam Negeri; 2017.

20. Cega G F,Yogaswara B. , Mardiansyah A. Analisis beban kerja dan kebutuhan tenaga kerja karyawan divisi logistik Di Pt Xyz menggunakan metode work sampling. E-proceeding of engineering: Desember 2017;4(3): 4525.

21. Rahmayanti. Gambaran sistem distribusi obat dan bahan medis habis pakai di instalsi farmasi rumah sakit umum (RSU) kota Tanggerang Selatan tahun 2017 [skripsi]. Jakarta: FKK Universitas Islam Negeri Syarif Hidayatullah; 2017.

22. Teichert MI, Luijben SN, Wereldsma A, Schalk $T$, Janssen J, Wensing $M$, de Smet $P$. Implementation of medication reviews in 
community pharmacies and their effect on potentially inappropriate drug use in elderly patients. International Journal of Clinical pharmacy. October 2013;35(5):19-21.
23. Moekijat. Manajemen personalia dan sumber daya manusia. Yogyakarta: BFFE; 2008.

24. Simamora H. Manajemen sumber daya manusia. Yogyakarta: Sekolah Tinggi IImu Ekonomi YKPN; 2006. 